\title{
PERAN HARGA PATOKAN (ANCHOR PRICE) TERHADAP KEPUTUSAN UNTUK MEMBELI SAHAM
}

\author{
TettyRimenda $^{1, \varpi)}$, R. Elly Mirati ${ }^{2)}$ \\ Jurusan Akuntansi Politeknik Negeri Jakarta \\ e-mail: ${ }^{1}$ tetty.rimenda@akuntansi.pnj.ac.id
}

\begin{abstract}
The purpose of this study is to examine the role of anchor prices in consumer decision making in buying shares. When buying shares someone has a benchmark or reference. This study uses positive information about the issuer as a reference to buy shares. The research method used is the $2 X 22$ experimental method (Price Display: Regular Price vs. Price + Info) x 2 (Stock Type: BKSL vs. WIKA. Participants are students who are also investors who are used to making transactions in the capital market. that information plays an important role for investors to decide to buy shares Investors prefer stocks whose prices are accompanied by information about the issuer. When expensive and cheaper shares are given information, it turns out investors prefer shares with high prices that are informed about the issuer.
\end{abstract}

Key words: Anchor price, stock, buying decision

\begin{abstract}
ABSTRAK
Tujuan penelitian ini adalah untuk menguji peran anchor price didalam pengambilan keputusan konsumen dalam melakukan pembelian saham. Ketika membeli saham sesorang memiliki patokan atau referensi. Penelitian ini menggunakan informasi positif tentang emiten sebagai referensi membeli saham. Metode penelitian yang dipakai adalah metode eksperimen $2 X 22$ (Tampilan Harga: Harga biasa vs. Harga + info) x 2 (Jenis Saham : BKSL vs.WIKA. Partisipan adalah mahasiswa yang juga sebagai investor yang sudah biasa bertransaksi di pasar modal. Hasil penelitian menyimpulkan bahwa informasi memegang peranan penting bagi investor untuk memutuskan membeli saham. Investor lebih memilih saham yang harganya disertai dengan informasi tentang emiten. Ketika saham yang mahal dan yang lebih murah, sama-sama diberi informasi, ternyata investor lebih memilih saham yang harganya mahal yang diberi informasi tentang emiten.
\end{abstract}

Kata kunci: Anchor price, saham, keputusan membeli

\section{PENDAHULUAN}

Ketika membeli suatu produk, sesorang memiliki batas harga tertinggi dimana ia bersedia membeli suatu produk (Willingness to Pay $=$ WTP) . Sebaliknya ketika menjual produk, ia juga memiliki batas harga terendah dimana ia bersedia untuk melepaskan produk yang dijualnya itu(Willingness to Accept = WTA). WTP maupun WTA adalah harga dimana sesorang dengan sukarela membeli atau menjual saham yang dimilikinya. Untuk menentukan WTP atau WTA seseorang pasti mempunyai standar yang akan menjadi patokan untuk sampai ke tahap WTP maupun WTA. Standart itu disebut dengan harga patokan (anchor price). Contoh sederhananya, saya baru saja mendapatkan warisan seharga 150 juta, dengan adanya uang tersebut maka saya bersedia membeli mobil, paling mahal seharga 150 juta, bila mendapatkan harga lebih murah dengan kualitas yang sama, maka itu adalah keberuntungan saya. Sehingga angka 150 juta menjadi harga patokan (anchor price) dalam membeli mobil. WTP saya maksimal 150 juta. Sebaliknya ketika saya ingin menjual rumah saya, saya juga memiliki harga patokan dimana saya bersedia melepas rumah saya. Misalnya tetangga saya baru menjual rumah yang kondisinya hampir sama dengan rumah saya seharga 200 juta, maka harga 200 
juta itu menjadi harga patokan (anchor price) untuk menjual rumah. Sehingga WTA saya adalah 200 juta. Bila saya berhasil menjual lebih mahal dari 200 juta, maka itu adalah keberuntungan saya, tapi saya tidak akan menjual rumah saya, dibawah harga 200 juta.

Harga adalah sejumlah uang yang dibayarkan untuk memperoleh produk atau jasa tertentu. Harga mencerminkan nilai produk atau jasa. Dalam setiap transaksi disarankan agar konsumen menilai terlebih dahulu nilai barang yang ditawarkan sebelum melakukan transaksi pembelian. Penilaian tersebut terdiri dari nilai perolehan, yaitu perbandingan antara manfaat dan biaya yang harus dikeluarkan untuk memperolehnya. Penilaian inilah yang dapat menjadi patokan bagi konsumen dalam membeli produk. Penelitian sebelumnya menyimpulkan bahwa harga patokan (anchor price) dipengaruhi oleh beberapa faktor, antara lain harga sebelumnya yang sudah diingat oleh konsumen, iklan harga yang disajikan secara komparatif dan lain-lain. Selain itu harga patokan (anchor price) sering juga didasarkan kepada hal-hal yang tidak masuk akal atau tidak rasional, tetapi bila konsumen sudah terpengaruh, maka ia akan tetap membeli produk tersebut. Bahkan penilaian mengatakan bahwa harga patokan (anchor price) dapat dimanipulasi, sehingga peran harga patokan ini dalam membeli produk sangat penting.

Dalam perdagangan saham, harga patokan menjadi suatu hal yang penting. Salah satu patokan dalam membeli saham adalah analisis fundamental, yaitu analisis untuk menentukan berapa nominal saham tersebut layak untuk dihargai. Metode yang dapat digunakan adalah Price Earning Ratio (PER) dan Price to Book Value Ratio (PBV). Untuk mengukur mahal atau murahnya, biasanya dibandingkan dengan saham dari industry yang sama. Selain itu ada juga analisa teknikal yang mengamati fluktuasi harga saham dalam rentang waktu tertentu. Dengan mengamati pola pergerakan harga saham, maka dapat diambil keputusan untuk membeli atau menjual saham. Dalam kenyataannya membeli atau menjual saham tidak berdasarkan patokan analisis fundamental atau teknikal semata, banyak investor yang membeli saham hanya berdasarkan harga patokan yang berasal dari rumor atau isu. Sehingga membeli saham sering dikatakan sebagai gambling atau berjudi.

Penelitian tentang harga patokan ini dimulai pada tahun 1979 oleh Kahneman dan Tversky, (1979), yang melakukan penelitian dari sudut pandang psikologi tentang pengambilan keputusan konsumen. Penelitian ini berkembang sejak tahun 1992, tetap dikembangkan oleh Kahneman dan Tversky, tetapi mulai memandang dari sudut ilmu pemasaran, yang dikenal sebagai teori of mind. Beberapa ahli kemudian mengembangkan Theory of mind dengan lebih mendalam sejak tahun 2007. Sehingga dapat dikatakan Theory of mind masih terbilang baru. Anchor price, merupakan bagian dari Theory of mind yang membahs tentang pengambilan keputusan dalam situasi yang tidak pasti, dimana orang harus mengambil keputusan dengan cepat, dan informasi yang dipunyainya sangat terbatas.

Pengambilan keputusan adalah pekerjaan yang sangat penting dan sering sekali beresiko. Kesalahan dalam pengambilan keputusan akan mengakibatkan kerugian dalam perusahaan. Dalam dunia investasi, pengambilan keputusan untuk memutuskan membeli atau menjual saham akan mengakibatkan kerugian yang beresiko besar secara pribadi, sehingga pengambilan keputusan untuk membeli saham merupakan keputusan yang sangat penting. Penelitian terdahulu menyimpulkan bahwa untuk mengambil suatu keputusan, seorang 
investor sangat membutuhkan suatu referensi (Mazumdar \& Sinh ; 2005). Selanjutnya mereka mengatakan bahwa harga referensi yang dimiliki oleh konsumen dan sering digunakan adalah referensi harga internal, yaitu informasi yang sudah tersimpan dibenak konsumen. Selanjutnya Kan dkk (2014) mengembangkan penelitian tentang harga referensi sebagai dasar pengambilan keputusan konsumen. Pada saat ini format harga sudah menjadi penilaian khusus dari Kan dkk, dimana penulisan harga \$ 199,90 dianggap lebih murah dibandingkan harga \$200,00, karena angka 1 dibenak konsumen lebih kecil dibandingkan angka 2. Sehingga refrensi berupa format harga sudah merupakan penilaian khusus dai konsumen.

Penelitian tentang theory of mind berlanjut menjadi penelitian harga patokan, sebenarnya harga patokan tidak jauh berbeda pengertiannya dengan harga referensi, hanya saja harga patokan lebih banyak dipakai dibidang yeng memerlukan pengambilan keutusan yang cepat dan beriko tinggi Furnham \& Chu Boo 2011. Dimana dikatakan pengambilan seperti ini sering sekali yang menjadi anchor adalah sesuatu yang bersifat heuristic yaitu sangat cepat, berdasar intuisi dan secara otomatis, sehingga kadang-kadang pengambilan keputusannya menjadi tidak rasional karena berdasarkan sesuatu yang tidak masuk akal.

Penelitian ini bertujuan untuk menguji pengambilan keputusan pembelian saham mahasiswa Politeknik Negeri Jakarta yang diberi informasi harga saham normal dan harga saham dengan memberikan informasi tentan emitennya. Apakah investor lebih memilih membeli harga saham dengan harga yang sebenarnya atau membeli harga saham dengan diberi informasi tentang emitennya

\section{METODE PENELITIAN}

Tujuan penelitian ini adalah untuk menguji pengaruh harga patokan (anchor price) terhadap pengambilan keputusan investor untuk membeli saham. Pengujian dilakukan dengan metoda eksperiment. Partisipan dibagi kepada 4 kelompok. Kelompok 1 adalah kelompok yang melihat harga saham BKSL (Bukit Sentul Rp. 138) . Kelompok 2 adalah kelompok yang melihat saham BKSL (Bukit Sentul dengan harga Rp. 138)dan diberi informasi BKSL . Kelompok 3 adalah kelompok yang melihat harga saham WIKA dengan harga Rp 2.050. Kelompok 4 adalah yang melihat sahan WIKA Rp 2.050 dengan diberi diberi informasi WIKA

Desain Penelitian yang dirancang adalah 2x2 yaitu 2 (Tampilan Harga vs. Harga + informasi) x 1 (Saham : BKSL Vs WIKA)

\begin{tabular}{|c|c|c|c|}
\multicolumn{2}{|c|}{ Tabel 1. Desain Penelitian } \\
\hline \multirow{4}{*}{ SAHAM } & \multicolumn{2}{|c|}{ HARGA SAHAM } \\
\cline { 3 - 4 } \multicolumn{1}{|c|}{ SAHAM } & BKSL & Rp. 138 & $\begin{array}{c}\text { Harga + } \\
\text { Info }\end{array}$ \\
\cline { 3 - 4 } & Info BKSL \\
\cline { 2 - 4 } & WIKA & Rp. 2.050 & $\begin{array}{c}\text { Rp. } 2.050 \\
+ \text { Info } \\
\text { WIKA }\end{array}$ \\
\cline { 2 - 4 } & &
\end{tabular}

\section{Pilot Study}

Pilot study dilakukan dua tahap. Tahap pertama untuk memilih saham yang akan dipakai dalam penelitian ini. Dipilih 3 saham yang bergerak dibidang infrastruktur dengan pertimbangan saham ini diprediksikan akan meningkat harganya karena pesatnya pembangunan infrasturuktur di Indonesia. Kebetulan saham Infrastruktur pada saat penelitian sedang mengalami penurunan. Saham yang dipilih adalah 1. WIKA (Wijaya Karya), 2. PTPP (PT.Pembangunan Perumahan) 3. BKSL (Bukit Sentul) 4. WSKT (Waskita Karya). Pilot study 
yang dilakukan terhadap 30 mahasiswa Program study manajemen keuangan Politeknik Negeri Jakarta diperoleh komposisi yang memilih saham adalah $\mathrm{WIKA}=10 . \mathrm{PTPP}=7, \mathrm{BKSL}=8$, $\mathrm{WSKT}=5$.

Pilot study yang kedua bertujuan untuk memberi informasi positif tentang saham atau informasi negatif tentang saham. Partisipan sebanyak 20 orang. Hasil pilot study $80 \%$ partispan memilih informasi positif tentang saham, sehingga dalam eksperimen, dipakai informasi yang positif.

Jumlah partisipan sebanyak 100 orang yaitu mahasiswa Politeknik Negeri
Jakarta, program studi Keuengan Perbankan yang memang diwajibkan untuk menjadi investor di Galeri Investasi Politeknik Negeri Jakarta, dengan demikian mereka sudah pernah melakukan transaksi pembelian dan penjualan saham di galeri investasi Politeknik Negeri Jakarta

Prosedur eksperimen seperti dalam bagan dibawah ini. Untuk pelaksanaannya diperlukan bantuan dari beberapa orang mahasiswa, sebagai asisten pelaksana eksperimen. Sebelum melaksanakan eksperimen, mahasiswa tersebut akan dilatih terlebih dahulu.

Grafik 1. Prosedur Eksperimen

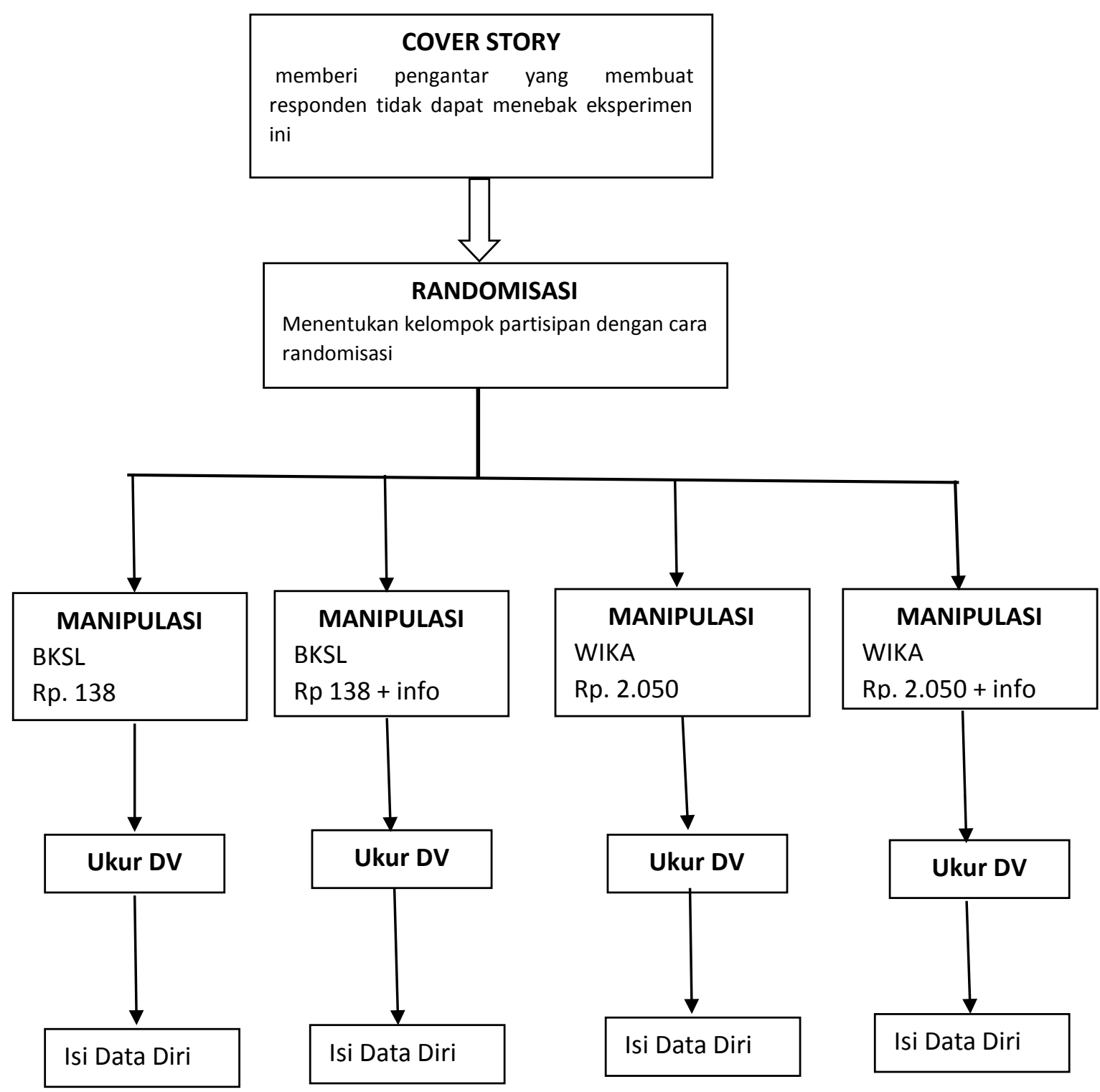




\section{HASIL DAN PEMBAHAN}

Partisipan pada penelitian ini adalah mahasiswa Politeknik Negeri Jakarta yang sudah menjadi investor di Galeri Investasi PNJ. Partisipan berjumlah 100 orang dengan komposisi 55 orang perempuan dan 45 orang laki-laki. Pada pelaksanaan eksperimen mereka dibagi kepada 4 kelompok yang dilakukan dengan cara undian. Jumlah perkelompoknya sama yaitu 25 orang perkelompok. Pengolahan data dilakukan dengan Compare Mean. Berdasarkan hasil output Uji Independent T-Test diperoleh hasil compare mean sbb

Tabel 2. Hasil Uji Independent T-Test

\begin{tabular}{lllc}
\hline & N & Mean & SIG (2 TAILED) \\
\hline BKSL & 25 & 316.040 & 0,005 \\
BKSLI & 25 & 257.400 & \\
WIKA & 25 & 338.800 & 0,112 \\
WIKAI & 25 & 368.040 & \\
BKSL & 25 & 316.040 & 0,253 \\
WIKA & 25 & 338.800 & \\
BKSLI & 25 & 257.400 & 0,00 \\
WIKAI & 25 & 368.040 & \\
\hline
\end{tabular}

Dari hasil pengujian compare mean diperoleh hasil bahwa terdapat perbedaan antara BKSL dan BKSLI, dengan rata-rata BKSL lebih besar dibandingkan BKSLI Selanjutnya hasil t test menunjukkan nilai sig sebesar 0,005 $<0.05$, dimana dapat disimpulkan bahwa terdapat perbedaaan antara BKSL dengan BKSLI. Dimana investor lebih memilih membeli saham BKSL dengan harga yang sebenarnya tanpa diberi informasi tambahan tentang emitennya. Diduga hal ini terjadi karena harga BKSL yang relatif masih murah, sehingga investor lebih mudah untuk membelanjakan uangnya tanpa perlu informasi yang lebih detail
Sedangkan hasil uji comapre mean antara WIKA dan WIKAI, terdapat perbedaan yang menunjukkan WIKAI lebih disukai, tetapi ketika diuji lanjut menunjukkan sig 0,112> 0.05, perbedaan tersebut tidak signifikan. Dengan demikian dalam membeli saham WIKA investor tidak mempermasalahkan membeli harga yang sebenarnya, maupu mambeli dengan harga yang diberi informasi.

Ketika dibandingkan antara harga saham yang BKSL dan WIKA yang sama-sama tidak diberi informasi, ternyata perbedaannya tidak signifikan 0, 253> 0,05 , artinya investor tidak membedakan harga saham yang tidak diberi informasi, mereka tetap menganggap sama, sehingga pembelian sahamnya hanya berdasarkan dana yang dimiliki.

Sedangkan ketika kedua saham samasama diberi informasi, ternyata terdapat perbedaan yang signifikan dimana investor lebih menyukai saham WIKA yang diberi informasi. Diduga hal ini karena saham WIKA harganya lebih mahal, sehingga investor lebih berhatihati dalam membeli sahamnya.

\section{KESIMPULAN}

Kesimpulan penelitian ini, saham yang diberi informasi lebih memberi pengaruh kepada investor dalam menentukan pembelian sahamnya. Ketika saham yang harganya mahal dan harganya lebih murah sama-sama diberi informasi, diperoleh hasil bahwa saham yang berharga mahal yang diberi informasi lebih disukai oleh investor. Engan demikian pemberian informasi sangat dibutuhkan oleh investor sebelum membeli saham 


\section{DAFTAR PUSTAKA}

[1] Furnham Adrian \& Chuu Boo, Hua (2011) A literature review of the Anchoring Effect, The Journal of Socio-economics, 40 (2011), pp 3542

[2] Kahneman, Daniel \& Tversky, Amos (1979) Prospect Theory: An Analysis of Decision under Risk, Econometrica, Vol. 47, No. 2. (Mar., 1979), pp. 263-292

[3] Kan Christina, Lichtenstein Donald R, Grant, Susan Jung, Janiszewski Chris (2014 ) : Strengthening the Influence of Advertised Reference Prices through Information Priming, Journal Of Consumer Research Vol. 40, April 2014

[4] Mazumdar Tridib, S.P. Raj, \& Sinha Indrajit ( 2005) : Reference Price Research:Review and Propositions, Journal of Marketing Vol. 69 (October 2005), 84-102

[5] Nunes, Joseph C \& Boatwright (2004) : Incidental Prices and Their Effect on Willingness to Pay Journal of Marketing Research Vol. XLI (November 2004), 457-466457

[6] Tversky, Amos \& Kahneman, Daniel (1992), Advances in Prospect Theory: Cumulative Representation of Uncertainty Journal of Risk and Uncertainty, 5:297-323 (1992) 